The Book of Beginnings 
This page intentionally left blank 


\section{The Book of Beginnings}

FRANÇOIS JULLIEN

TRANSLATED BY JODY GLADDING

YALE UNIVERSITY PRESS $₫$ NEW HAVEN \& LONDON

\section{A MARGELLOS}


The Margellos World Republic of Letters is dedicated to making literary works from around the globe available in English through translation. It brings to the Englishspeaking world the work of leading poets, novelists, essayists, philosophers, and playwrights from Europe, Latin America, Africa, Asia, and the Middle East to stimulate international discourse and creative exchange.

English translation copyright (C) 2015 by Yale University. Translated by Jody Gladding. Originally published as Entrer dans une pensée, ou Des possibles de l'esprit.

Copyright () Editions GALLIMARD, Paris, 2012.

All rights reserved. This book may not be reproduced, in whole or in part, including illustrations, in any form (beyond that copying permitted by Sections 107 and 108 of the U.S. Copyright Law and except by reviewers for the public press), without written permission from the publishers.

Yale University Press books may be purchased in quantity for educational, business, or promotional use. For information, please e-mail sales.press@yale.edu (U.S. office) or sales@yaleup.co.uk (U.K. office).

Printed in the United States of America.

Library of Congress Cataloging-in-Publication Data

Jullien, François, 1951-

[Entrer dans une pensée. English]

The book of beginnings / François Jullien ; translated by Jody Gladding.

pages $\mathrm{cm}$. - (The Margellos world republic of letters)

ISBN 978-0-300-20422-3 (cloth : alk. paper)

1. Thought and thinking. 2. Philosophy, Chinese. I. Title.

B105.T54J8513 $2015 \quad 109-\mathrm{dc} 23 \quad 2014031911$

A catalogue record for this book is available from the British Library.

This paper meets the requirements of ANSI/NISO Z39.48-1992 (Permanence of Paper).

10987654321 